\author{
Володимир Петрович Нагребельний, \\ заступник директора Інституту держсави і права \\ ім. В. М. Корецького НАН України з наукової роботи, \\ кандидат юридичних наук, член-кореспондент НАПрН Украӥни, \\ заслужений юрист Украӥни
}

\title{
В АВАНГАРДІ УКРАЇНСЬКОЇ АКАДЕМІЧНОЇ ЮРИДИЧНОЇ НАУКИ
}

\author{
Інститут держави і права імені В. М. Корецького НАН Украйни \\ відзначив свій 70-річний ювілей
}

\begin{abstract}
У травні 2019 р. виповнилося 70 років з часу створення Інституту держави і права імені В. М. Корецького НАН України. За період свого існування Інститут пройшов непростий шлях свого становлення й розвитку. Долаючи труднощі, він з невеликого Сектора держави та права АН УРСР перетворився на провідну наукову академічну юридичну установу країни. Своїм творчим доробком у дослідженні фундаментальних проблем історії та теорії держави і права, державно-правового будівництва, правової політології, а також міжнародного права і порівняльного правознавства Інститут здобув широке визнання серед юридичної громадськості в Україні та за її межами.

Створення у повоєнні роки правознавчої академічної дослідницької установи ініціював видатний український вчений-правознавець, академік АН УРСР Володимир Михайлович Корецький. Така установа була потрібна передусім для теоретичного обгрунтування міжнародної правосуб' єктності Української РСР, яка на той час стала членом $\mathrm{OOH}, \mathrm{i}$ для надання допомоги Міністерству закордонних справ УРСР у його діяльності. Спочатку це був Сектор держави і права АН УРСР (заснований згідно з постановою Президії АН УРСР від 13 травня 1949 р.), на базі якого двадцять років поспіль, у 1969 р. був створений відповідний Інститут. Наказом № 9 по АН УРСР від 12 серпня 1949 р. завідувачем Сектора держави і права АН УРСР (з 11 липня) було призначено академіка АН УРСР В. М. Корецького.

Відповідно до постанови Ради Міністрів УРСР від 6 травня 1949 р. Президія АН УРСР визначила такі основні напрями науково-дослідної діяльності Сектора: історія держави і права Української РСР; міжнародне право (насамперед проблеми, пов'язані з діяльністю УРСР як країни-учасниці ООН і суб'єкта міжнародного права); питання державного права країн народної демократії.

Становлення Сектора відбувалося в умовах жорсткої сталінської командно-адміністративної системи і домінування класового підходу до дослідження суспільних відносин і державно-правових явищ. Перші наукові праці, опубліковані співробітниками Сектора, були присвячені питанням міжнародного права (В. М. Корецький), возз'єднання українських земель в єдину радянську державу та організації правознавчих наукових досліджень (Б. М. Бабій). В 1952 р. було започатковане багатотомне видання наукових записок Сектора держави і права АН УРСР.

Хрущовська «відлига» позитивно вплинула на стан і характер наукової діяльності Сектора, зросла кількість науковців Сектора і розширилася дослідницька тематика, зокрема, за рахунок розробки проблем історії держави і права, державного, адміністративного, цивільного, трудового і колгоспного права, кримінального права і кримінального процесу, правової охорони природи тощо.

У 1961 р. у складі Сектора були організовані науково-галузеві групи на громадських засадах. Надалі, відповідно до постанови Президії АН УРСР від 30 грудня 1965 р. було утворено чотири науково-дослідні відділи: а) теоретичних і конституційних проблем Радянської держави (завідувач - Б. М. Бабій); б) проблем державного і господарського управління (завідувач - А. П. Таранов); в) з дослідження причин і розробки заходів щодо запобігання злочинності (завідувач - I. П. Ла-
\end{abstract}


новенко); г) проблем міжнародно-правової діяльності УРСР і порівняльного державознавства (завідувач - В. М. Корецький).

У 1966 р. Сектор поповнився ще одним відділом - проблем радянського будівництва (завідувач - В. М. Терлецький), а відділ І. П. Лановенка було перейменовано на відділ проблем соціалістичної законності і кримінології. Б. М. Бабій обійняв посаду заступника завідувача Сектора і фактично керував ним, оскільки В. М. Корецький з 1960 по 1970 р. перебував у Гаазі на посаді судді Міжнародного суду ООН, а згодом - заступника голови суду.

Проведені у вказаний період науково-організаційні заходи дали можливість ефективніше проводити фундаментальні, правові дослідження у Секторі, зміцнити його зв'язки з юридичною практикою. Значно зросла роль Сектора як установи 3 координації наукових державно-правових досліджень у республіці, збільшилася кількість публікацій, у тому числі колективних монографічних праць. Помітним явищем, зокрема, стала одна з них - «Політична організація суспільства» за редакцією Б. М. Бабія (1967р.).

31950 по 1968 рр. науковцями Сектора було підготовлено і опубліковано 92 монографії, 73 брошури і понад 320 наукових статей. За цими показниками, а також за кількісним і якісним складом, Сектор наблизився до категорії наукової установи у формі академічного науководослідного інституту.

У зв'язку з цим було поставлено питання про надання Секторові статусу академічного інституту. Це питання з розумінням було сприйняте Президією АН УРСР і особисто президентом академії академіком Б. Є. Патоном. Після подолання численних бюрократичних перепон він домігся від Москви згоди на перетворення Сектора в Інститут держави і права. 12 червня 1969 р. Рада Міністрів УРСР ухвалила постанову за № 360 «Про створення Інституту держави і права Академії наук УРСР», на виконання якої Президія АН УРСР 24 червня 1969 р. ухвалила постанову за № 202 «Про створення Інституту держави і права АН УРСР». Цією постановою Інститут було включено до складу Відділу економіки, історії, філософії та права АН УРСР. Виконувачем обов'язків директора Інституту було призначено В. М. Корецького, а заступником директора з наукової роботи - Б. М. Бабія.

Постановою Президії АН УРСР від 24 червня 1969 р. були визначені основні напрями наукових досліджень Інституту, а саме: а) дослідження актуальних проблем радянського державного будівництва і розвитку Української РСР як складової єдиної багатонаціональної соціалістичної держави - СРСР; б) розробка теоретичної спадщини з питань утворення Української радянської держави; в) дослідження проблем, пов'язаних з удосконаленням законодавства УРСР; г) дослідження проблем управління народним господарством УРСР і правового регулювання господарських відносин в УРСР; д) вивчення найважливіших питань зміцнення соціалістичної законності, запобігання і викорінення злочинності й розробка заходів щодо посилення боротьби з порушеннями громадського порядку в УРСР; е) дослідження теоретичних проблем міжнародно-правової діяльності УРСР; ж) критика ревізіоністських поглядів з питань розвитку української соціалістичної державності.

У 1974 р. академік АН УРСР Б. М. Бабій був призначений директором Інституту, а В. М. Корецький - почесним директором. У листопаді наступного року Інститут перемістився у приміщення по вул. Трьохсвятительській, 4 , у якому знаходиться і нині.

У другій половині 1970-х - на початку 1980-х років неодноразово здійснювалася реорганізація структури Інституту, а кількість наукових відділів зросла до восьми. Інститут зміцнив творчі зв'язки $з$ органами державної влади та вищими юридичними навчальними закладами України, а також з Інститутом держави і права АН СРСР, Всесоюзним науково-дослідним інститутом радянського законодавства, Всесоюзним інститутом з вивчення причин і розробки заходів запобігання злочинності та ін.

Крім підготовки фундаментальних монографічних праць 3 державознавства і правознавства, Інститут розгорнув програму популяризації юридичних знань. Декілька разів перевидавався «Юридичний довідник для населення»; в 1974 р. побачив світ «Юридичний словник» за редакцією Б. М. Бабія, В. М. Корецького і В. В. Цвєткова, а у 1985 р. - «Російсько-український словник юридичної термінології» за редакцією Б. М. Бабія. Протягом 1975-1985 pp. у республіканському видавництві «Знання» було опубліковано низку науково-популярних брошур з правової тематики.

У 1977-1978 рр. Інститут узяв активну участь у підготовці проекту Конституції УРСР 1978 p. Б. М. Бабій був членом робочої групи і секретаріату з підготовки проекту Основного Закону. Він, а також В. С. Бражников, І. П. Бутко, А. П. Таранов і В. М. Терлецький, очолювали робочі підгрупи з відповідних напрямів і питань. 
У 1980 р. академіку В. М. Корецькому виповнилося 90 років. За визначні заслуги у розвитку юридичної науки, підготовці наукових кадрів та активну громадсько-політичну діяльність йому було присвоєно звання Героя соціалістичної праці, що стало безпрецедентною подією в історії радянської юридичної науки.

Наступного року інститутський двотомник «Історія держави і права Української РСР» отримав Державну премію УРСР у галузі науки і техніки (відповідальний редактор - Б. М. Бабій, співавтори - В. М. Терлецький, А. П. Таранов, В. В. Мрига, В. С. Бражников та ін.).

Розпочата в середині 80-х років горбачовська перебудова суспільного життя в Радянському Союзі демократизувала процеси наукотворення і зменшила ідеологічний тиск на соціогуманітарні науки. Це збіглося зі зміною керівництва Інституту. В жовтні 1988 р. Президія АН УРСР затвердила на посаді директора Інституту Ю. С. Шемшученка (члена-кореспондента АН УРСР, а згодом академіка НАН України), який очолює Інститут і нині.

Під його керівництвом була розроблена і впроваджена система заходів щодо перебудови наукової діяльності Інституту на основі перегляду та переосмислення ідеологічних стереотипів і догм у галузі держави і права, які дісталися у спадок від командно-адміністративної системи і репресивного судочинства. Відповідно, по-новому були визначені пріоритетні напрями наукових досліджень, вдосконалена організаційна структура Інституту, урізноманітнились форми зв'язків юридичної науки з практикою. 3 метою поліпшення координації фундаментальних наукових досліджень у 1990 р. із провідних учених Інституту на громадських засадах було утворено дві наукові ради «Проблеми правової держави, захист і забезпечення прав особи» $\mathrm{i}$ «Проблеми сучасної політичної системи, господарського механізму і управління».

Якісно новий етап у діяльності Інституту розпочався з ухваленням в 1990 р. Декларації про державний суверенітет України та Акта проголошення незалежності України (1991). У цей період відбулися істотні зміни в підходах до проблем державознавства і правознавства, оскільки відповідні державно-правові феномени розпочали розглядати не в площині загальносоюзної політико-правової системи, а як явища суверенної держави.

З урахуванням цього наукові дослідження Інституту держави і права АН (з 1995 р. - НАН) України були спрямовані на створення юридичної наукової бази для становлення й розвитку української суверенної держави та ії̈ правової системи, здійснення конституційної, адміністративної, судовоправової та інших реформ. У лютому 1990 р. постановою Ради Міністрів УРСР Інституту держави і права присвоєно ім'я В. М. Корецького.

Пріоритетними напрямами наукових досліджень Інституту у першій половині 90-х років були: розбудова державності України; проблеми конституційного права й місцевого самоврядування; правового регулювання аграрних відносин та охорони навколишнього середовища; боротьби з економічними та іншими злочинами; міжнародного права й міжнародної правосуб'єктності України: теоретичні та прикладні проблеми розвитку правової системи України; Україна в системі сучасного міжнародного правопорядку. Ці напрями є пріоритетними для Інституту й тепер, з одним доповненням: з 1996 р. до категорії пріоритетних віднесено теоретичні дослідження проблем реалізації Конституції України.

8 вересня 1993 р. Президія НАН України прийняла постанову «Про підготовку фундаментальної «Юридичної енциклопедії», а 22 лютого 1996 р. Кабінет Міністрів України ухвалив постанову «Про державну підтримку видання «Юридичної енциклопедії». Зважаючи на важливість цього питання, підготовку «Юридичної енциклопедії» (у 6 томах) також було віднесено до пріоритетних напрямів наукової діяльності Інституту.

На початку 90-х років відбулися й певні структурні зміни в Інституті. Довелося відмовитися від наукових секторів. Після проведення уточнень визначені такі назви 8 наукових відділів Інституту: історико-політологічних досліджень держави і права України; конституційного права, місцевого самоврядування та проблем законності; цивільного і трудового права; державно-правових проблем управління; правових проблем екології і аграрного права; кримінально-правових і кримінологічних проблем, міжнародного права.

У 1992 р. в Інституті було започатковано міжвідомчий збірник наукових праць «Правова держава». 31994 р. цей збірник виходить як щорічник наукових праць Інституту. Протягом 90-х років науковці Інституту опублікували десятки монографічних праць з актуальних проблем державно-правового будівництва у суверенній Україні, теорії та історії держави і права, міжнародного права та ін. 
У 90-х роках в Інституті, насамперед зусиллями професора Ю. І. Римаренка, було започатковано новий напрям наукових досліджень - етнодержавознаство. На основі проведених досліджень було видано серію монографічних та енциклопедичних праць із цих питань. 3 довідкової літератури, науково-популярної і виданої у ці роки Інститутом, варто назвати: «Юридичний довідник підприємця» (1992, за редакцією В. Б.Авер'янова), «Юридичний словник-довідник» (1996, за редакцією Ю. С. Шемшученка і В. Д. Бабкіна), «Власність громадян. Юридичний довідник» (1997, за редакцією Я. М. Шевченко), «Політологічний енциклопедичний словник» (1997), «Мала енциклопедія етнодержавознавства» (1996), «Міграційні процеси в сучасному світі» (1997).

У першій половині 90-х років в Інституті було розпочато видання серії «Пам'ятки політико-правової культури України», зокрема: «Зібрання малоросійських прав 1807 р.» за редакцією Б. М. Бабія та О. М. Мироненка (1993); «Ділова документація Гетьманщини ХУШ ст.» (1993); «Права, за якими судиться малоросійський народ» за редакцією Ю. С. Шемшученка (1997). Новим напрямом діяльності інституту стала підготовка й видання підручників та навчальних посібників, зокрема, підручників: «Основи правознавства» за редакцією І. Б. Усенка (1997); «Основи етнодержавознавства» за редакцією Ю. І. Римаренка (1997); «Кооперативне право» за редакцією В. І. Семчика (1998); «Конституційне право України» за редакцією В. Ф. Погорілка (1999) та ін.

Упродовж 90-х років наукові праці інституту неодноразово були відзначені академічними та іншими преміями і нагородами. Зокрема, у 1991 р. премію АН України імені Д. З. Мануїльського отримали Ю. С. Шемшученко й Н. р. Малишева - за цикл праць з правових проблем охорони навколишнього середовища. Премією НАН України імені М. П. Василенка були відзначені В. Н. Денисов i В. В. Євінтов - за цикл праць «Міжнародне право і світовий порядок: пошук моделей правового розвитку» (1992); І. Б. Усенко - за цикл праць «Юридичні аспекти історії Всеукраїнської академії наук» (1994); О. М. Костенко - за цикл праць «Закон і злочин (соціопсихологічні дослідження) (1995); Ю. І. Римаренко - за цикл праць «Етнодержавознавство: понятійний апарат, концептуальні підходи, теорія і практика» (1996); Ю. С. Шемшученко і К. А. Вислобоков - за видання видатної пам’ятки українського права «Права, за якими судиться малоросійський народ» (1997).

У травні 1999 р. Інститут урочисто відзначив свій 50-річний ювілей і був нагороджений Почесною грамотою Кабінету Міністрів України. До цієї дати була видана грунтовна праця про історію становлення й розвитку Інституту - «Інститут держави і права ім. В. М. Корецького НАН України. Наукові досягнення за 50 років».

Впродовж 1999-2004 рр. наукові дослідження в Інституті велися за такими пріоритетними напрямами: проблеми державотворення в Україні: теорія, історія, практика; теоретичні і прикладні проблеми розвитку правової системи України; теоретичні проблеми реалізації Конституції України; Україна в системі сучасного міжнародного правопорядку: теорія і практика; підготовка і видання «Юридичної енциклопедії» у 6 томах. Крім традиційної для Інституту проблематики, активно почали розвиватися й нові напрями наукових досліджень, зокрема, актуальних проблем інтелектуальної власності, банківського, енергетичного, ядерного й космічного права, правової політології, порівняльного правознавства тощо.

Протягом 1999-2004 рр. співробітники Інституту опублікували понад 100 монографічних праць, 70 посібників і довідників, близько тисячі наукових статей. Особливе значення серед них мали монографічні роботи за результатами наукових досліджень. Їх кількість зросла, якщо порівняти з попереднім п'ятиріччям, майже удвічі. Це свідчення того, що Інститут продовжував залишатися провідним науково-правовим центром країни, а його внесок у розвиток вітчизняної юридичної науки - найвагомішим.

Значним результатом наукової діяльності Інституту за цей період стало завершення підготовки й видання 6-томної «Юридичної енциклопедії» (голова редакційної колегії Ю. С. Шемшученко), над яким плідно працював Центр енциклопедичних видань Інституту. Ця багатотомна унікальна праця була відзначена Державною премією України в галузі науки і техніки 2004 р.

Інститут також брав участь у підготовці енциклопедичних видань разом 3 іншими науководослідними установами й вищими навчальними закладами. Зокрема, у 2000-2001 pp. Інститут спільно з Державною академією керівних кадрів культури і мистецтв видав «Енциклопедію етнокультурознавства» у 3 книгах (голова редколегії Ю. І. Римаренко). Наприкінці 2003 р. побачив світ перший том багатотомної «Міжнародної поліцейської енциклопедії», провідна роль у виданні якої належить Національній академії внутрішніх справ України та Інституту держави і права 
ім. В. М. Корецького НАН України. Відповідальними редакторами цього видання від інституту були Ю. І. Римаренко та Ю. С. Шемшученко.

Окремо слід вказати про започаткування у 2001 р. видання Інститутом десятитомної «Антології української юридичної думки» (за заг. ред. Ю. С. Шемшученка), до підготовки якої були залучені практично всі наукові відділи Інституту. Антологія закумулювала найвагоміші здобутки української юридичної думки майже за 250 років. Це видання сприятиме вивченню та узагальненню вітчизняного досвіду для розвитку сучасної юридичної думки й вирішенню практичних державноправових проблем сьогодення.

Важливо зазначити, що у цей час розширилися можливості Інституту для оперативного оприлюднення результатів наукових досліджень. Інститут став співвидавцем журналів «Право України» та «Підприємництво і право», видає щорічник наукових праць «Правова держава». Популярним серед молодих учених та аспірантів став започаткований у 1997 р. інститутський збірник наукових праць «Держава і право», $з$ періодичністю видання чотири рази на рік.

Значно зміцнилися традиційні зв'язки Інституту з Верховною Радою України, Адміністрацією Президента і Кабінетом Міністрів України, міністерствами і відомствами, місцевими державними адміністраціями, Київською міською та іншими місцевими радами, судами, органами прокуратури тощо. Зміцніли зв'язки з Конституційним Судом України, для якого Інститут готував експертні науково-правові висновки.

Науковці Інституту брали участь у роботі науково-консультативних рад при Верховному Суді України, Вищому господарському суді України, Прокуратурі України, Міністерстві юстиції України 3 підготовки законопроектів, експертних рад ВАК України з атестації наукових кадрів. До відповідних державних органів було подано низку важливих законопроектів (Земельний кодекс України, Екологічний кодекс України, Трудовий кодекс України) та ін.

Випробуваною часом формою апробації наукових результатів були міжнародні й національні наукові та науково-практичні конференції, які проводив Інститут. Визнаною формою спілкування вчених і практиків стали методологічні семінари Інституту, які започатковані у 1999 р., котрі він проводив за участі юридичної фірми «Салком» (рада засновників - Ю. С. Шемшученко, С. Б. Кубко, В. В. Цвєтков). На семінарах обговорювались актуальні проблеми державно-правового розвитку країни, ухвалювали наукові рекомендації. Так, упродовж 1999-2004 рр. були проведені такі методологічні семінари: «Актуальні проблеми судово-правової реформи в Україні» (1999); «Зовнішньополітична діяльність України та ії правове забезпечення» (2000); «Парламентаризм в Україні: теорія і практика» (2001); «Адміністративна реформа: стан та перспективи» (2001); «Земельний кодекс України: проблеми реалізації» (2002); «Конституційно-правові проблеми українського державотворення» (2002); «Цивільний та Господарський кодекси України: проблеми теорії та практики реалізації» (2003); «Громадянське суспільство і держава в Україні: проблеми взаємодії» (2004).

У 2002 р. структура Інституту поповнилася дев'ятим відділом - правових проблем політології (завідувач - I. О. Кресіна). У межах цього відділу проводилися дослідження проблем етнодержавознавства (Ю. І. Римаренко), започатковані нові теми досліджень з питань політики і права, взаємодії держави і громадянського суспільства тощо.

В науково-організаційному аспекті характерною особливістю кінця XX - початку XXI ст. стало створення в інституті нових структурних підрозділів - шести наукових центрів: Міжнародного центру космічного права; Центру банківського права; Міжнародного центру правових проблем інтелектуальної власності; Центру місцевого самоврядування; Центру енергетичного та ядерного права; Центру порівняльного правознавства. На відміну від традиційних відділів, наукові центри, як відомо, більш автономні структурні одиниці, котрі є однією з ефективних форм інтеграції юридичної науки і практики. 3 утворенням наукових центрів Інститут розширив тематику прикладних досліджень, розпочав підготовку фахівців нового профілю (космічне право, банківське право, право інтелектуальної власності, енергетичне та ядерне право тощо).

На особливу увагу заслуговує участь учених Інституту в конституційних проектах незалежної України. Зокрема, в Інституті при підготовці проекту Конституції України 1996 р. були розроблені й надіслані до відповідних державних органів наукова концепція і проект Основного Закону. Директор Інституту академік НАН України Ю. С. Шемшученко був членом Конституційної комісії Верховної Ради України, а В. Б. Авер'янов, І. П. Бутко, Л. Т. Кривенко та В. Ф. Погорілко входили до складу офіційних робочих груп з підготовки проекту Конституції. І. Б. Усенко взяв участь у остаточному термінологічному редагуванні тексту Конституції. 
Наприкінці 2010 р. в Інституті працювали близько 100 наукових співробітників, у тому числі майже 90 докторів і кандидатів юридичних наук, 13 академіків та членів-кореспондентів НАН України і Академії правових наук України, 10 заслужених діячів науки і техніки та заслужених юристів України.

У 2011-2013 рр. провідні науковці Інституту працювали у складі Конституційної Асамблеї з підготовки проекту Концепції щодо змін до Конституції України. До цієї роботи були залучені Ю. С. Шемшученко (заступник Голови Асамблеї), О.В.Скрипнюк, О. І. Ющик, Н. М. Пархоменко, В. Ф. Сіренко, М. О. Пухтинський та ін. На даний час вони беруть участь у підготовці проекту змін до Конституції України у рамках діяльності Конституційної комісії, утвореної у 2014 р. парламентом України.

Головними структурними одиницями Інституту у цей час були 10 наукових відділів: теорії держави і права (завідувач Н. М. Оніщенко); історико-правових досліджень (завідувач І. Б. Усенко); конституційного права та місцевого самоврядування (завідувач Ю. С. Шемшученко); проблем державного управління та адміністративного права (завідувач О. Ф. Андрійко); проблем цивільного, трудового та підприємницького права (завідувач Н. М. Хуторян); проблем аграрного та земельного права (завідувач П. Ф. Кулинич); космічного та екологічного права (завідувач Н. Р. Малишева); проблем кримінального права, кримінології та судоустрою (завідувач О. М. Костенко); міжнародного права та порівняльного правознавства (завідувач В. Н. Денисов); правових проблем політології (завідувач І. О. Кресіна).

Крім того, у складі чи при Інституті діють 8 наукових центрів, а також Рада по координації фундаментальних правових досліджень НАН України (голова Ю. С. Шемшученко).

Інститут поглибив творчі зв'язки з Національною академією правових наук України. У цей період Інститут разом з цією академією підготував і видав фундаментальні п’ятитомні праці «Правова система України» та «Правова доктрина України». Також було започатковано підготовку і видання Української юридичної енциклопедії в 20 томах.

Традиційно розвивались зв'язки з Національним юридичним університетом імені Ярослава Мудрого, юридичними факультетами Київського національного університету імені Тараса Шевченка та Львівського національного університету ім. Івана Франка, Національним університетом «Одеська юридична академія», Національною академією внутрішніх справ та Харківським національним університетом внутрішніх справ, ДВНЗ «Українська академія банківської справи Національного банку України», Інститутом міжнародних відносин Київського національного університету імені Тараса Шевченка тощо.

У цей час Інститут активно проводив національні і міжнародні наукові конференції та симпозіуми. Разом Національним космічним агентством України він, зокрема, провів у Києві у 2006 р. Міжнародний симпозіум $\mathrm{OOH} з$ космічного права, який отримав широкий резонанс. Крім того, співробітники Інституту включалися до складу міжнародних делегацій України, в тому числі на сесії Генеральної Асамблеї ООН.

Наукова діяльність Інституту на національному рівні здійснювалася у контексті ії інтеграції з юридичною освітою. При цьому використовувались різноманітні ії форми. Зокрема, провідні вчені Інституту залучалися до читання курсів лекцій у багатьох провідних навчальних закладах країни.

Справжньою школою для апробації наукових ідей стали методологічні семінари «Юридична наука і суспільство: проблеми теорії і практики». До участі у семінарах, крім науковців, залучалися народні депутати України, відомі державні і громадські діячі. Науковий і практичний інтерес, зокрема, викликали такі методологічні семінари останніх років: «Громадянське суспільство і держава в Україні: проблеми взаємодії» (доповідь академіка НАН України О. С. Онищенка); «Національна держава і право в умовах глобалізації» (доповідь академіка В. М. Литвина); «Проблеми організації державної влади в Україні» (доповідь академіка НАН України Ю. С. Шемшученка); «Конституційно-правові засади державного суверенітету України в умовах глобалізації: проблеми теорії і практики» (доповіді першого Президента України Л. М. Кравчука та академіка В. М. Гейця) та ін.

Кардинальні зміни в політичному і соціально-економічному житті країни, які відбулися після Революції Гідності у 2014 році, обумовили необхідність коригування науково-дослідницької проблематики Інституту, розширення його зв'язків з практикою державотворення і правотворення в умовах реальних загроз і викликів для України, пов'язаних з анексією Російською Федерацією Криму, розв'язанням нею війни на Донбасі.

Головними напрямами наукової діяльності Інституту впродовж 2014-2019 рр. стали: проблеми державотворення і правотворення, реалізації Конституції України та модернізації правової системи 
України; правові проблеми формування громадянського суспільства, забезпечення прав і свобод людини та громадянина; проблеми організації законодавчої, виконавчої та судової влади в Україні; правові проблеми національної безпеки України; правові проблеми економічної, енергетичної та екологічної безпеки України, боротьби з корупцією та злочинністю; розвиток і вдосконалення національного інформаційного законодавства; правове забезпечення наукової та науково-технічної діяльності в Україні; Україна в системі сучасного міжнародного правопорядку та європейської інтеграції; політико-правові механізми протидії сепаратизму, формування національної ідентичності населення Донбасу, реінтеграції Донбасу і Криму, відновлення територіальної цілісності держави, політико-правові засади миротворчої операції в Донбасі та ін.

Науково-дослідницька діяльність Інституту концентрується на проведенні та координації фундаментальних правових досліджень, спрямованих на отримання та використання нових знань у галузі правознавства та правової політології. Лише протягом 2014-2019 pр. Інститутом було виконано 9 тем науково-дослідних робіт. Ці теми охоплюють всю царину юридичної науки та правової політології, включаючи проблеми теорії держави і права, історико-правових досліджень, конституційного права та місцевого самоврядування, цивільного, трудового і підприємницького права, аграрного, земельного, екологічного та космічного права; державного управління та адміністративного права, кримінального права, кримінології та судоустрою, міжнародного права та порівняльного правознавства, правових проблем політології та інші актуальні у наш час проблеми, зокрема актуальні проблеми розвитку України як суверенної, демократичної, правової, соціальної держави та її інтеграції в міжнародний і європейський правовий простір.

Про високий інтелектуальний потенціал Інституту може свідчити те, що на даний час у ньому працюють близько 80 докторів і кандидатів наук. Серед учених Інституту один академік та один член-кореспондент НАН України, 14 академіків і членів-кореспондентів Національної академії правових наук України, 8 заслужених діячів науки і техніки України, 11 заслужених юристів України, 10 лауреатів Державної премії України у галузі науки і техніки.

Важливим здобутком колективу Інституту є його наукові школи, які сформувалися протягом усього періоду діяльності Інституту, зокрема, школи: міжнародного права, історико-правових досліджень, конституційного права, державного управління та адміністративного права, теорії держави і права, аграрного, земельного та екологічного права, кримінального права.

Майбутнє Інституту безпосередньо пов'язане з вдосконаленням організації наукових досліджень, підвищенням їх ефективності і практичної значущості. На це, зокрема, спрямована схвалена вченою радою 2018 р. Стратегія розвитку Інституту держави і права імені В. М. Корецького на найближчу перспективу. дана стратегія передбачає системний, цілеспрямований і збалансований розвиток Інституту, пріоритетні напрями наукових досліджень, зміцнення зв'язків 3 органами державної влади і органами місцевого самоврядування, поліпшення координації фундаментальних правових досліджень, вдосконалення форм міжнародного наукового співробітництва тощо. Чільне місце у стратегії відведено підготовці наукових кадрів вищої кваліфікації через докторантуру та аспірантуру. Зараз в аспірантурі Інституту навчається понад 100 осіб, діють три спеціалізовані вчені ради із захисту докторських і кандидатських дисертацій. Щороку в цих радах захищається у середньому понад 50 відповідних дисертаційних робіт.

У цілому злагоджена робота колективу Інституту протягом багатьох років дала змогу зробити значний внесок у розвиток вітчизняної юридичної науки та розбудову правової системи Української держави. За 70 років науковцями Інституту опубліковано близько 750 монографій, понад 350 підручників, збірників, довідників і словників, 550 брошур, майже 5500 наукових статей $з$ юридичної тематики. Серед найвагоміших досягнень науковців Інституту останніх років шеститомна «Юридична енциклопедія», десятитомна «Антологія української юридичної думки», трьохтомна «Енциклопедія міжнародного права», «Енциклопедія цивільного права», «Мала енциклопедія права інтелектуальної власності», «Великий енциклопедичний юридичний словник» та ін.

Отже, 70-річний досвід діяльності Інституту держави і права імені В. М. Корецького НАН України свідчить про те, що він завжди займав провідні позиції в українській юридичній науці. Свою наукову, просвітницьку і громадянську місію Інститут виконує і зараз. Його творчий пошук у сучасних складних умовах політичного, соціального та економічного розвитку спрямований на розбудову в Україні дійсно демократичної, правової соціальної держави і розвинутого громадянського суспільства. 
В рамках відзначення 70-річного ювілею Інституту 13 травня 2019 р. відбулось урочисте відкриття меморіальної дошки засновнику Інституту академіку В. М. Корецькому у місті Києві по вул. Богдана Хмельницького, 42 на будинку, в якому він впродовж тривалого часу жив і працював. Учасники зібрання відзначили визначний внесок В. М. Корецького у розвиток української юридичної науки, поділились спогадами про нього як видатного вченого-правознавця і непересічну людину.

14 травня 2019 р. Інститут організував проведення міжнародної науково-практичної конференції «Юридична наука: сучасний стан та перспективи розвитку». Конференцію було організовано 3 метою визначення сучасного стану та перспектив розвитку юридичної науки. 3 вступним привітал ним словом виступили академік-секретар Відділення історії, філософії та права НАН України, академік НАН України $\boldsymbol{C м о л і и ̆ ~} \boldsymbol{B}$. $\boldsymbol{A}$., директор Інституту держави і права ім. В. М. Корецького, академік НАН України Шемшученко Ю. $\boldsymbol{C}$., директор Інституту законодавства Верховної Ради України, академік НАН України Копиленко О. Л., президент Національної академії правових наук України, академік НАПрН України Петришин $\boldsymbol{O}$. $\boldsymbol{B}$.

На конференції виступили з доповідями: Шемшученко Ю. С. (директор Інституту держави і права ім. В. М. Корецького НАН України, доктор юридичних наук, професор, академік НАН України, академік НАПрН України); Скрипнюк О. В. (заступник директора з наукової роботи Інституту держави і права ім. В. М. Корецького НАН України, доктор юридичних наук, професор, академік НАПрН України); Кузнєцова $\boldsymbol{H}$. $\boldsymbol{C}$. (доктор юридичних наук, професор, академік НАПрН України, віце-президент НАПрН України - керівник Київського регіонального центру НАПрН України); Оніщенко Н. M. (завідувач відділом теорії держави і права Інституту держави і права ім. В. М. Корецького НАН України, доктор юридичних наук, професор, академік НАПрН України); Оніщук $\boldsymbol{M}$. B. (ректор Національної школи суддів України, доктор юридичних наук, професор); Сіренко В. Ф. (головний науковий співробітник Інституту держави і права ім. В. М. Корецького НАН України, доктор юридичних наук, професор, член-кореспондент НАН України, академік НАПрН України); Денисов В. $\boldsymbol{H}$. (завідувач відділу міжнародного права та порівняльного правознавства Інституту держави і права ім. В. М. Корецького НАН України, доктор юридичних наук, професор, член-кореспондент НАПрН України); Селіванов $\boldsymbol{A}$. $\boldsymbol{O}$. (доктор юридичних наук, професор, академік НАПрН України, постійний представник Верховної Ради України в Конституційному Суді України); Карпунцов В. B. (народний депутат України, доктор юридичних наук); Уільям Елліотm Батлер (США) (доктор $\mathrm{PhD}$, іноземний член НАН України та НАПрН України); Topdiя В. B. (генеральний секретар Асоціації суддів країн-підписантів Меморандуму співпраці: Вірменії, Грузії, Естонії, України, Казахстану та Польщі); Нагребельний В. П. (заступник директора з наукової роботи Інституту держави і права ім. В. М. Корецького НАН України, кандидат юридичних наук, членкореспондент НАПрН України); Сівець С. M. (Республіка Білорусь) (заступник директора - керівник Інституту правових досліджень Національного центру законодавства і правових досліджень Республіки Білорусь, кандидат юридичних наук, доцент); Костенко О. М. (завідувач відділом проблем кримінального права, кримінології та судоустрою Інституту держави і права ім. В. М. Корецького НАН України, доктор юридичних наук, професор, академік НАПрН України); Фружсіна ГардошOpoc (Угорщина) (директор Інституту правових досліджень Наукового центру суспільних наук Угорської Академії наук, старший науковий співробітник); Пархоменко $\boldsymbol{H}$. M. (вчений секретар Інституту держави і права ім. В. М. Корецького НАН України, доктор юридичних наук, професор); Чаба Варга (Угорщина) (доктор юридичних наук, професор, почесний професор-дослідник Інституту правових досліджень Наукового центру суспільних наук Угорської академії наук, почесний професор Католицького університету імені Петера Пажмані); Кресіна I. O. (завідувач відділу правових проблем політології Інституту держави і права ім. В. М. Корецького НАН України, доктор політичних наук, професор, член-кореспондент НАПрН України); Андрійко О. Ф. (завідувач відділу проблем державного управління та адміністративного права Інституту держави і права ім. В. М. Корецького НАН України, доктор юридичних наук, професор, член-кореспондент НАПрН України); Усенко I. Б. (завідувач відділу історико-правових досліджень Інституту держави і права ім. В. М. Корецького НАН України, професор); Антонов В. О. (провідний науковий співробітник Інституту держави і права ім. В. М. Корецького НАН України, доктор юридичних наук, доцент); Батанов О. B. (провідний науковий співробітник Інституту держави і права ім. В. М. Корецького НАН України, доктор юридичних наук, професор); Кресін $\boldsymbol{O}$. В. (доктор юридичних наук, завідувач Центру порівняльного правознавства Інституту держави і права ім. В. М. Корецького НАН України). 
У роботі конференції взяли участь народні депутати України, керівні працівники Кабінету Міністрів України, Національної академії наук України, Національної академії правових наук України, а також науковці, викладачі вищих навчальних та науково-дослідних установ юридичного профілю України.

Основними питаннями дискусії на конференції були: теоретико-методологічні засади реформування державної влади в Україні; проблеми реформування політичної системи і публічної влади в Україні; проблеми забезпечення політико-правової реформи: необхідність, поняття, зміст, проблеми і перспективи реалізації в Україні; поділ і єдність державної влади в Україні: питання співвідношення; державна влада і місцеве самоврядування в Україні; утвердження парламентаризму - ключовий фактор розвитку України як демократичної правової держави; адміністративна реформа в контексті здійснення політико-правової реформи в Україні; судово-правова реформа в Україні: необхідність, концептуальні засади, проблеми реалізації; конституційний процес і розвиток національної правової системи; проблеми організації державної влади в контексті європейської інтеграції України тощо.

Заслухавши та обговоривши наукові доповіді і повідомлення з актуальних проблем розвитку юридичної науки на сучасному етапі, учасники міжнародної науково-практичної конференції відзначили, що за останнє десятиріччя правова наука в Україні і на всьому пострадянському просторі набула нових рис і стала більш творчою у теоретичному обгрунтуванні та практичному вирішенні проблем державотворення і правотворення. Значно посилилися теоретико-методологічний, порівняльно-правовий та прогностичний аспекти юридичної науки. Результати досліджень одержали своє відображення в численних монографічних працях, енциклопедичних виданнях, навчальних підручниках, наукових статтях тощо. В цілому сучасна вітчизняна юридична наука справляє позитивний вплив на практику розв'язання актуальних проблем державно-правового будівництва, розвитку демократичної, соціальної, правової держави і громадянського суспільства, поглиблення євроатлантичної інтеграції.

Водночас творчий потенціал юридичної науки, зокрема, в Україні, використовується ще недостатньо. Більшість економічних і соціальних реформ, передусім конституційної, адміністративно-територіальної, судово-правової, місцевого самоврядування та децентралізації влади потребують належного наукового супроводу і забезпечення. Значна кількість наукових висновків, пропозицій і рекомендацій не базується на глибокому пізнанні практики правозастосування, широкому використанні результатів соціогуманітарних наук. Існують певні проблеми, пов'язані з методологією юридичної науки, прогнозуванням і моделюванням у праві. Українська юридична наука ще недостатньо спирається на відповідні міжнародні і європейські стандарти. На окрему увагу заслуговує розробка наукових засад систематизації та кодифікації законодавства, визначення стратегії розвитку правової системи України на найближчу перспективу в умовах євроатлантичного цивілізаційного вибору.

3 огляду на викладене, учасники конференції визнали за доцільне:

- вжити заходів до удосконалення методологічної бази юридичної науки, розробки сучасних методологічних підходів до пізнання правових явищ, додаткового розширення використання порівняльно-правового методу як основи для адекватної оцінки відповідних соціально-правових явищ і суспільних відносин. 3 цією метою слід підвищувати роль і значення методологічних семінарів 3 актуальних проблем державно-правового розвитку, які проводяться на базі Інституту держави і права імені В. М. Корецького НАН України;

- розширити і поглибити проблематику правознавчих досліджень, що стосуються як традиційних галузей права (конституційне, адміністративне, цивільне, трудове, земельне, кримінальне, міжнародне право), так і нових, зокрема, комплексних галузей і підгалузей права (екологічне, аграрне, господарське, енергетичне, інвестиційне, транспортне, банківське право, право інтелектуальної власності, космічне, європейське право тощо);

- поглибити теоретичні дослідження проблем реалізації принципів верховенства права з точки зору забезпечення ефективної реалізації правових норм і приписів, а також дослідження проблеми співвідношення політики і права, взаємодії держави і громадянського суспільства;

- вжити заходів щодо наукової оцінки ефективності реформаційних законів, враховуючи, що їх реалізація передбачає наявність певного перехідного етапу, який нерідко супроводжується гострими правовими колізіями в законодавстві, неоднозначним тлумаченням його положень; 
- активізувати теоретичну розробку проблем конституційного права і правової політології під кутом зору їх більшого впливу на процеси оновлення Конституції України, розвитку парламентаризму, забезпечення прав і свобод людини;

- посилити дослідження соціальних чинників, що обумовлюють потребу реформування законодавства у сфері правосуддя 3 метою правового унормування суспільних відносин відповідно до принципу верховенства права, охорони та захисту прав і свобод громадян;

- розширити інтеграцію юридичної науки і юридичної освіти, а саме проведення спільних досліджень науковими установами юридичного профілю та юридичних факультетів в вищих навчальних закладах;

- посилити вплив юридичної науки на формування правової свідомості і правової культури громадян і посадових осіб, у зв’язку з чим продовжити підготовку видання енциклопедичної і словникової юридичної літератури, а також академічних підручників для вищих юридичних навчальних закладів;

- вжити заходів до більш широкого залучення до наукової юридичної діяльності молодих кадрів, підвищити якість їх підготовки через аспірантуру і докторантуру;

- поліпшити якість підготовки докторів філософії та докторів юридичних наук для науководослідних установ і вищих навчальних закладів;

- вжити заходів до формування у суспільстві високої правової духовності, правових ідеалів справедливості, демократизму, свободи і рівності, гуманізму;

- з метою концентрації зусиль на розробці актуальних проблем державознавства і правознавства, усунення дублювань у правових дослідженнях посилити роль наукової ради з координації фундаментальних правових досліджень НАН України.

Після завершення конференції відбулися розширені урочисті ювілейні збори колективу Інституту. Збори відкрив директор Інституту академік НАН України Ю. С. Шемшученко, який розповів присутнім про етапи створення, становлення та розвитку Інституту, охарактеризував основні результати його 70-річної діяльності, окреслив їі перспективи на майбутнє.

Перед учасниками зборів виступив віце-президент НАН України академік НАН України С. І. Пирожков, який оголосив привітання колективу Інституту президента Національної академії наук України академіка НАН України Б. С. Патона. В. о. голови Комітету Верховної Ради України 3 питань науки та освіти О. В. Співаковський високо оцінив діяльність Інституту в законотворенні і від імені голови парламенту А. В. Парубія вручив колективу Інституту Грамоту Верховної Ради України.

3 ювілеєм Інституту його колектив привітали: президент Національної академії правових наук України академік НАПрН України О. В. Петришин, директор Інституту законодавства Верховної Ради України академік НАН України О. Л. Копиленко, перший заступник голови Союзу юристів України Н. І. Карпачова; директор Інституту історії НАН України академік НАН України В. А. Смолій; декан юридичного факультету Київського національного університету імені Тараса Шевченка професор І. С. Гриценко; директор Інституту філософії імені Г. С. Сковороди НАН України, член-кореспондент НАН України А. М. Срмоленко; директор Інституту політичних і етнонаціональних досліджень імені І. Ф. Кураса НАН України академік НАН України О. О. Рафальський; ректор Київського університету права НАН України професор Ю. Л. Бошицький; перший проректор Національної академії внутрішніх справ професор С. Д. Гусарсв; народні депутати України, відповідальні працівники Кабінету Міністрів України, низки міністерств і відомств, правоохоронних і судових органів та ін.

У зв'язку з 70-річчям від дня заснування Інституту держави ті права імені В. М. Корецького НАН України, за вагомий особистий внесок у розвиток юридичної науки, підготовку наукових кадрів, активну участь у науковому забезпеченні правотворчої і правозастосовної діяльності провідні наукові співробітники відзначені високими державними і відомчими нагородами. Зокрема, головного наукового співробітника відділу теорії держави і права, члена-кореспондента Сіренка В. Ф. - нагороджено Орденом князя Ярослава Мудрого V ступеня; завідувача відділу проблем аграрного, земельного, екологічного та космічного права доктора юридичних наук, професора Малишеву Н. Р. - Орденом «За заслуги» III ступеня; провідному науковому співробітнику відділу проблем аграрного, земельного, екологічного та космічного права, доктору юридичних наук, професор Кулиничу П. Ф. - присвоєно почесне звання «Заслужений діяч науки і техніки України»; 
провідному науковому співробітнику відділу правових проблем політології, доктору політичних наук, професору Горбатенку В. П. - присвоєно почесне звання «Заслужений діяч науки і техніки України»; Почесною грамотою Верховної Ради України відзначено: Горбатенка В. П. провідного наукового співробітника відділу правових проблем політології Інституту, доктора політичних наук, профессора; Батанова О. В., провідного наукового співробітника відділу конституційного права та місцевого самоврядування Інституту, доктора юридичних наук, профессора; Кресіна О. В., провідного наукового співробітника відділу міжнародного права та порівняльного правознавства Інституту, доктора юридичних наук, старшого наукового співробітника; Почесною грамотою Кабінету Міністрів України нагороджено: Усенка І. Б. Подякою Кабінету Міністрів України: старшого наукового співробітника відділу проблем цивільного, трудового та підприємницького права, кандидата юридичних наук Венецьку М. В., старшого наукового співробітника відділу міжнародного права та порівняльного правознавства, кандидата юридичних наук Савчука К. О., старшого наукового співробітника відділу теорії держави і права, кандидата юридичних наук Тарахонич T. I.; Почесною грамотою Президії НАН України - провідного наукового співробітника відділу міжнародного права та порівняльного правознавства, доктора юридичних наук, професора Акуленка В. І., провідного наукового співробітника відділу проблем цивільного, трудового та підприємницького права, доктора юридичних наук Тимченка Г. П., провідного наукового співробітника відділу правових проблем політології, доктора політичних наук Стойко О. М., старшого наукового співробітника відділу правових проблем політології, доктора політичних наук Явір В. А., старшого наукового співробітника відділу проблем цивільного, трудового та підприємницького права, кандидата юридичних наук Сімутіну Я. В., старшого наукового співробітника відділу проблем цивільного, трудового та підприємницького права, кандидата юридичних наук Бабаскіна А. Ю., старшого наукового співробітника відділу проблем аграрного, земельного, екологічного та космічного права кандидата географічних наук Олещенка В. І., завідувача бібліотекою Інституту Овчиннікову Н. І.; Подякою Президії НАН України - провідного наукового співробітника відділу конституційного права та місцевого самоврядування кандидата юридичних наук Мурашина Г. О., старшого наукового співробітника відділу теорії держави і права кандидата юридичних наук Богініча О. Л., старшого наукового співробітника відділу конституційного права та місцевого самоврядування кандидата юридичних наук Пухтинського М. О., старшого наукового співробітника відділу проблем державного управління та адміністративного права кандидата юридичних наук Воротіну Н. В., старшого наукового співробітника відділу теорії держави і права кандидата юридичних наук Макаренко Л. О., старшого наукового співробітника відділу міжнародного права та порівняльного правознавства кандидата юридичних наук Переверзєву О. С.; Відзнакою Президії НАН України «За професійні здобутки»: старшого наукового співробітника відділу проблем державного управління та адміністративного права кандидата юридичних наук Ісаєву Н. К., головного бухгалтера Інституту Давидову Н. О.; Відзнакою Президії НАН України для молодих учених: старшого наукового співробітника відділу історико-правових досліджень, кандидата юридичних наук Малишева О. О.; Подякою Голови Київської міської державної адміністрації Кличка В. В.: провідного наукового співробітника відділу конституційного права та місцевого самоврядування, доктора юридичних наук Антонова В. О.; старшого наукового співробітника відділу проблем цивільного, трудового та підприємницького права кандидата юридичних наук Севрюкову I. Ф.; старшого наукового співробітника відділу теорії держави і права кандидата юридичних наук Львову О. Л., старшого наукового співробітника відділу міжнародного права та порівняльного правознавства кандидата юридичних наук Проценко І. М., старшого наукового співробітника відділу проблем кримінального права, кримінології та судоустрою кандидата юридичних наук Нерсесяна А. С., наукового співробітника відділу конституційного права та місцевого самоврядування кандидата юридичних наук Омельченко Н. Л.; старших наукових співробітників, кандидатів політичних наук Кукуруз О. В., Ходаківського М. Д. наукового співробітника кандидата юридичних наук Батанову Н. М. відділу правових проблем політології; Почесною грамотою Союзу юристів - заступника директора з наукової роботи Інституту кандидата юридичних наук Нагребельного В. П.; старших наукових співробітників кандидатів юридичних наук Самойленко О. О., Іванову А. Ю., Музику І. В., Бондарук Т. І. та наукового співробітника кандидата юридичних наук Худояр Л. В. відділу історико-правових досліджень; старших наукових співробітників кандидатів юридичних наук відділу конституційного права та місцевого самоврядування Костецьку Т. А., Гаєву Н. К.; 
старших наукових співробітників кандидатів юридичних наук відділу проблем державного управління та адміністративного права Кисіль Л. Є., Тимощука В. П.; старшого наукового співробітника Сірого М. І., та наукового співробітника Кубальського В. Н. кандидатів юридичних наук відділу проблем кримінального права. кримінології та судоустрою; наукового співробітника відділу проблем цивільного, трудового та підприємницького права кандидата юридичних наук Молявко О. М.; Орденом «За заслуги» I ступеня Союзу юристів України: Шемшученка Ю. С., директора Інституту, академіка НАН України, академіка Національної академії правових наук України, доктора юридичних наук, професора, Заслуженого діяча науки і техніки України; Орденом «За заслуги» II ступеня Союзу юристів України: Сіренка В. Ф., головного наукового співробітника відділу теорії держави і права Інституту, доктора юридичних наук, професора, члена-кореспондента НАН України Орденом «За заслуги» III ступеня Союзу юристів України: Скрипнюка О. В., заступника директора Інституту, академіка Національної академії правових наук України, доктора юридичних наук, професора.

У зв'язку з 70-річчям від дня заснування, вагомий внесок у розвиток юридичної науки, підготовку наукових кадрів, державотворення і право творення трудовий колектив Інституту відзначений Почесною грамотою Союзу юристів України.

Характеризуються основні етапи становлення і розвитку провідної наукової юридичної установи Украйни - Інституту держави і права імені В. М. Корецького НАН Украӥни за 70 років (19492019 рр.). Аналізуються основні напрями його наукової діяльності, творчі досягнення протягом семи десятиліть і перспективи правових досліджень, форми і результати зв'язків з практикою державно-правового будівництва в Україні, міжнародне наукове співробітництво та ін. Особливу увагу приділено характеристиці сучасного, якісно нового етапу в діяльності Інституту в умовах подальшого демократичного розвитку Украӥнської держави та ї̈ євроінтеграційного вибору, висвітлюються заходи з відзначення 70-річчя Інституту.

DOI: 10.33.66.3/2524-017X-2019-10-9-20 